Finanse, Rynki Finansowe, Ubezpieczenia nr 3/2017 (87), cz. 1

\title{
Finansowanie rozwoju jednostki samorządu terytorialnego ze źródeł zewnętrznych jako zadanie doradcze audytu wewnętrznego
}

\author{
Wanda Skoczylas, Anna Kulczyńska*
}

\begin{abstract}
Streszczenie: $C e l$ - Identyfikacja zagrożeń w absorbcji zewnętrznych źródeł finansowania, a w tym środków Unii Europejskiej w perspektywie lat 2014-2020 w realizacji przedsięwzięć twardych i miękkich poprawiających jakość życia społeczności lokalnej.

Metodologia badania - Wykorzystano metodę krytycznej analizy literatury i pozostałych źródeł, analizę ryzyka oraz case study wybranego powiatu.

Wynik - Przeprowadzone badanie pozwoliło potwierdzić rosnące znaczenie funkcji doradczej audytu wewnętrznego oraz istniejące zagrożenia w absorpcji środków Unii Europejskiej przez samorządy i ich determinanty. W konkluzji uzasadniono i potwierdzono potrzebę rozszerzenia katalogu wyłączeń przy obliczaniu indywidualnego wskaźnika zadłużenia.

Oryginalność/wartość - Zaproponowanie i uzasadnienie - w wyniku realizacji funkcji doradczej audytu wewnętrznego - rozszerzenia katalogu wyłączeń uwzględnianych przy obliczaniu indywidualnego wskaźnika zadłużenia, mających wpływ na eliminację bariery absorpcji środków Unii Europejskiej oraz poprawę gospodarnego działania na rzecz społeczności lokalnej bez zwiększania zadłużenia.
\end{abstract}

Słowa kluczowe: audyt wewnętrzny, funkcja doradcza, finansowanie rozwoju, indywidualny wskaźnik zadłużenia

\section{Wprowadzenie}

Przegląd definicji audytu wewnętrznego pozwala jednoznacznie stwierdzić, że pełni on obok funkcji zapewniającej także funkcję doradczą. Podstawowym celem funkcjonowania jednostek samorządu terytorialnego jest poprawa jakości życia społeczności lokalnej lub regionalnej. Jego realizacja niewątpliwie związana jest z inwestycjami, często kapitałochłonnymi, co wiąże się z pozyskaniem zewnętrznych źródeł finansowania, w tym środków z Unii Europejskiej oraz funduszy celowych. Poziom zadłużenia jednostki samorządu terytorialnego wyznacza indywidualny wskaźnik zadłużenia, który wskazuje na możliwość jednostki w zakresie spłaty i obsługi zobowiązań (określa wysokość środków jakie można przeznaczyć na rozchody budżetu). Rzecz w tym, że jednorazowo pozyskane pomocowe środki zewnętrzne negatywnie oddziałują na omawiany wskaźnik, analogicznie

\footnotetext{
" prof. zw. dr hab. Wanda Skoczylas, Uniwersytet Szczeciński, WNEiZ, Instytut Rachunkowości, e-mail: wanda@ wneiz.pl; mgr Anna Kulczyńska, Skarbnik, Powiat Sulęciński, e-mail: anna.kulczynska@powiatsulecinski.pl.
} 
jak zabezpieczenie środków na wkład własny z nadwyżki z lat ubiegłych i posiadanych „wolnych środków”. Efektem jest ograniczenie dostępu jednostki samorządu terytorialnego do środków zewnętrznych, a także mniejsza możliwość efektywnego gospodarowania środkami budżetu. Analiza postępów w zakresie wykorzystania środków przyznanych Polsce przez Unię Europejską nie pozwala na pozytywną ocenę działań samorządów w tym zakresie. Problem ten więc ma wymiar ogólnokrajowy, co podkreśla jego aktualność i ważność.

Celem artykułu jest identyfikacja zagrożeń w absorbcji zewnętrznych źródeł finansowania, w tym środków Unii Europejskiej w perspektywie lat 2014-2020 w realizacji przedsięwzięć twardych i miękkich, poprawiających jakość życia społeczności lokalnej.

W realizacji tak sformułowanego celu wykorzystano metodę krytycznej analizy literatury i pozostałych źródeł, analizę ryzyka oraz case study wybranego powiatu.

\section{Funkcja doradcza audytu wewnętrznego}

Definicja w ustawie o finansach publicznych określa audyt wewnętrzny jako „działalność niezależną i obiektywną, której celem jest wspieranie ministra kierującego działem lub kierownika jednostki w realizacji celów i zadań przez systematyczną ocenę kontroli zarządczej oraz czynności doradcze" (Dz.U. 2016 poz. 1870, art. 272, ust. 1).

Jak więc wynika z przedstawionej definicji, audyt wewnętrzny obok funkcji zapewniającej pełni także funkcję doradczą. Podobnie funkcje te zostały zapisane w definicji Instytutu Audytorów Wewnętrznych, gdzie twierdzi się, że: „Audyt wewnętrzny jest działalnością niezależną i obiektywną, której celem jest przysporzenie wartości i usprawnienie działalności operacyjnej organizacji. Polega na systematycznej i dokonywanej w uporządkowany sposób ocenie procesów zarządzania ryzykiem, kontroli i ładu organizacyjnego i przyczynia się do poprawy ich działania. Pomaga organizacji osiągnąć cele dostarczając zapewnienia o skuteczności tych procesów, jak również poprzez doradztwo" (Definicja, 2016, s. 3). Przy czym „Usługi doradcze, ze względu na swój charakter, wykonywane są zwykle w odpowiedzi na konkretne zapotrzebowanie zleceniodawcy" (Definicja, 2016, s. 11). Dalej zaś zwraca się uwagę, że: „W trakcie wykonywania zadań doradczych audytorzy wewnętrzni muszą odnieść się do ryzyk powiązanych z celami zadania. Muszą być także wyczuleni na możliwość istnienia innych znaczących ryzyk. Audytorzy wewnętrzni muszą wykorzystywać wiedzę o ryzykach uzyskaną w trakcie wykonywania zadań doradczych do oceny procesów zarządzania ryzykiem w organizacji” (Definicja, 2016, s. 32). Można więc stwierdzić, że celem usług doradczych jest przysporzenie wartości i usprawnienie ocenianych procesów z zachowaniem zasady nieprzejmowania obowiązków kierownika jednostki.

Potwierdzenie pełnienia wymienionych funkcji znajdują się w definicjach innych autorów (Winiarska, 2007, s. 16; Herdan, Stuss, Krasodomska, 2009, s. 58-60). Ciekawym ujęciem jest prezentacja funkcji audytu wewnętrznego w świetle teorii systemów. P. Kabalski i L. Grzesiak twierdzą, że audyt wewnętrzny może funkcjonować jako homeostat i jako korelator. W pierwszym wypadku audyt wewnętrzny, monitorując, analizując procesy 
zachodzące w organizacji i w konsekwencji wychwytując negatywne wyjątki (błędy i nieprawidłowości), ma na celu utrzymanie stanu pożądanego i zapewnienie bieżącej równowagi. W drugim zaś wskazuje na możliwości usprawnień w funkcjonowaniu organizacji, a tym samym adaptację do warunków otoczenia oraz uczenie się, a jednostce pozwala wejść na wyższy poziom rozwoju. Jest to niezwykle istotne w erze informacji, gdzie liczy się wiedza jako wynik posiadania i przetwarzania informacji. Autorzy ci w ujęciu metaforycznym utożsamiają funkcję zapewniającą audytora z rolą policjanta, strażnika, nawigatora i anioła stróża. Dla audytora pełniącego funkcje doradcze widzą rolę mędrca, a więc kogoś kto ma najszerszą i najgłębszą wiedzę i może ją wykorzystać przy udzielaniu porad potrzebującym (Kowalski, Grzesiak, 2017). Realizacja funkcji doradczych determinowana jest poziomem dojrzałości organizacji, audytu wewnętrznego i zapotrzebowaniem kierownictwa jednostki. Przeprowadzone badania ankietowe wśród audytorów zatrudnionych w sektorze publicznym i prywatnym w Polsce potwierdziły wagę funkcji doradczej (w tym wskazanie możliwości usprawnień i rozwoju organizacji), chociaż widzą się oni w roli nawigatora (a więc w roli o nie najwyższym poziomie dojrzałości) wspomagającego zarządzających (Kabalski, Grzesiak, 2017).

\section{Ocena ryzyka wykorzystania środków Unii Europejskiej przez jednostki samorządu terytorialnego}

Można sformułować twierdzenie, że rozwój jednostki samorządu terytorialnego warunkowany jest dostępem do zewnętrznych źródeł finansowania, w tym do przydzielonych Polsce funduszy przez Unię Europejską. Wykorzystanie środków UE przedstawiono w tabeli 1.

\section{Tabela 1}

Wykorzystanie środków Unii Europejskiej w perspektywie 2014-2020 do końca 2015 roku

\begin{tabular}{|c|c|c|c|c|c|c|c|c|}
\hline Treść & $\begin{array}{l}\text { Budżet } \\
\text { w mld } \\
\text { euro }\end{array}$ & $\begin{array}{l}\text { Budżet } \\
\text { w mln zł według } \\
\text { kursu } 4,24\end{array}$ & $\begin{array}{l}\text { Wnioski } \\
\text { o dofnansowanie } \\
\text { wkład UE }\end{array}$ & $\begin{array}{l}\text { Procent } \\
\text { budżetu }\end{array}$ & $\begin{array}{l}\text { Umowy/decyzje } \\
\text { o dofinansowaniu } \\
\text { wkład UE }\end{array}$ & $\begin{array}{l}\text { Procent } \\
\text { budżetu }\end{array}$ & $\begin{array}{l}\text { Wnioski o płatność } \\
\text { - dofinansowanie } \\
\text { UE (zł) }\end{array}$ & $\begin{array}{l}\text { Procent } \\
\text { budżetu }\end{array}$ \\
\hline 1 & 2 & 3 & 4 & 5 & 6 & 7 & 8 & 9 \\
\hline PO Infrastruktura i Środowisko & 27,41 & 116218,4 & 10866,9 & 9,35 & 10628,1 & 9,14 & 1602,10 & 1,38 \\
\hline PO Inteligentny Rozwój & 8,61 & 36506,4 & 1100,3 & 3,01 & 588,8 & 1,61 & 0,00 & 0,00 \\
\hline PO Wiedza Edukacja Rozwój & 4,69 & 19885,6 & 4133,9 & 20,79 & 1349,4 & 6,79 & 239,00 & 1,20 \\
\hline PO Polska Cyfrowa & 2,17 & 9200,8 & 1917,7 & 20,84 & 667,3 & 7,25 & 1,00 & 0,01 \\
\hline PO Polska Wschodnia & 2,00 & 8480,0 & 4,7 & 0,06 & 1,8 & 0,02 & 0,05 & 0,00 \\
\hline PO Pomoc Techniczna & 0,70 & 2968,0 & 536,6 & 18,08 & 491,4 & 16,56 & 0,00 & 0,00 \\
\hline $\begin{array}{l}\text { PO Rozwoju Obszarów } \\
\text { Wiejskich }\end{array}$ & 8,60 & 36464,0 & b.d. & 0,00 & b.d. & 0,00 & b.d. & 0,00 \\
\hline PO Rybactwo i Morze & 0,50 & 2120,0 & b.d. & 0,00 & b.d. & 0,00 & b.d. & 0,00 \\
\hline $\begin{array}{l}\text { RPO województwa dolno- } \\
\text { śląskiego }\end{array}$ & 2,20 & 9328,0 & 96,0 & 1,03 & 53,3 & 0,57 & 0,03 & 0,00 \\
\hline $\begin{array}{l}\text { RPO województwa kujawsko- } \\
\text {-pomorskiego }\end{array}$ & 1,90 & 8056,0 & 57,8 & 0,72 & 53,9 & 0,67 & 4,00 & 0,05 \\
\hline RPO województwa lubelskiego & 2,20 & 9328,0 & 53,9 & 0,58 & 60,9 & 0,65 & 0,40 & 0,00 \\
\hline
\end{tabular}




\begin{tabular}{|c|c|c|c|c|c|c|c|c|}
\hline 1 & 2 & 3 & 4 & 5 & 6 & 7 & 8 & 9 \\
\hline RPO województwa lubuskiego & 0,90 & 3816,0 & 22,8 & 0,60 & 20,7 & 0,54 & 0,00 & 0,00 \\
\hline RPO województwa łódzkiego & 2,20 & 9328,0 & 200,4 & 2,15 & 151,8 & 1,63 & 15,10 & 0,16 \\
\hline $\begin{array}{l}\text { RPO województwa małopol- } \\
\text { skiego }\end{array}$ & 2,90 & 12296,0 & b.d. & 0,00 & b.d. & 0,00 & b.d. & 0,00 \\
\hline $\begin{array}{l}\text { RPO województwa mazo- } \\
\text { wieckiego }\end{array}$ & 2,10 & 8904,0 & 213,7 & 2,40 & 213,7 & 2,40 & 0,00 & 0,00 \\
\hline RPO województwa opolskiego & 0,90 & 3816,0 & 329,9 & 8,65 & 144,7 & 3,79 & 2,80 & 0,07 \\
\hline $\begin{array}{l}\text { RPO województwa podkar- } \\
\text { packiego }\end{array}$ & 2,10 & 8904,0 & 71,7 & 0,81 & 39,0 & 0,44 & 0,00 & 0,00 \\
\hline $\begin{array}{l}\text { RPO województwa podla- } \\
\text { skiego }\end{array}$ & 1,20 & 5088,0 & 386,8 & 7,60 & 39,5 & 0,78 & 4,10 & 0,08 \\
\hline $\begin{array}{l}\text { RPO województwa pomor- } \\
\text { skiego }\end{array}$ & 1,90 & 8056,0 & 345,9 & 4,29 & 126,5 & 1,57 & 0,00 & 0,00 \\
\hline RPO województwa śląskiego & 3,40 & 14416,0 & b.d. & 0,00 & b.d. & 0,00 & b.d. & 0,00 \\
\hline $\begin{array}{l}\text { RPO województwa warmińsko } \\
\text { mazurskiego }\end{array}$ & 1,70 & 7208,0 & 51,9 & 0,72 & 51,9 & 0,72 & 0,00 & 0,00 \\
\hline $\begin{array}{l}\text { RPO województwa zachodnio- } \\
\text { pomorskiego }\end{array}$ & 1,60 & 6784,0 & 36,4 & 0,54 & 25,4 & 0,37 & 0,00 & 0,00 \\
\hline $\begin{array}{l}\text { RPO województwa święto- } \\
\text { krzyskiego }\end{array}$ & 1,40 & 5936,0 & 116,7 & 1,97 & 57,9 & 0,98 & 0,00 & 0,00 \\
\hline $\begin{array}{l}\text { RPO województwa wielko- } \\
\text { polskiego }\end{array}$ & 2,40 & 10176,0 & 109,5 & 1,08 & 79,8 & 0,78 & 0,00 & 0,00 \\
\hline $\begin{array}{l}\text { Interreg V-A Polska - Sak- } \\
\text { sonia* }\end{array}$ & 0,70 & 2968,0 & 44,4 & 1,50 & 0,0 & 0,00 & 0,00 & 0,00 \\
\hline Razem & 86,40 & 366251,2 & 20697,9 & 5,65 & 14845,8 & 4,05 & 1868,58 & 0,51 \\
\hline
\end{tabular}

* Wartości dla programów EWT, które w SL2014 prezentowane są w euro, przeliczono zgodnie z kursem obowiązującym w przedmiotowym sprawozdaniu, tj. 1 euro $=4,24 \mathrm{zł}$.

Źródło: opracowanie własne na podstawie Sprawozdanie (2016), s. 11, https://www.funduszeeuropejskie.gov. pl/wszystkie-serwisy-programow.

Jak wynika z przedstawionych danych, w Polsce w analizowanym okresie zapoczątkowano dopiero wykorzystywanie przyznanych środków. Dalsza ich absorpcja określona jest m.in. poziomem dotychczasowego zadłużenia oraz rozwiązaniami dotyczącymi instrumentów określających możliwości zadłużania się, w tym konstrukcji indywidualnego wskaźnika zadłużenia.

Zadłużenie jednostek samorządu terytorialnego w roku 2015 przedstawiono na rysunku 1.

W roku 2015, w którym zadłużenie jednostek samorządu terytorialnego - za wyjątkiem powiatów - uległo zmniejszeniu, wskaźnik zadłużenia liczony jako relacja zobowiązań do wykonanych dochodów ogółem dla wszystkich jednostek wyniósł 36,0\%. Najbardziej zadłużone były miasta na prawach powiatu $(47,1 \%)$ oraz województwa $(41,8)$. Skalę zadłużenia jednostek samorządu terytorialnego określa też udział zadłużonych jednostek. W ocenianym roku zadłużonych (bez zobowiązań na realizację programów i projektów z udziałem środków unijnych) było 2707 jednostek (96,4\%), w tym z zadłużeniem do $40 \%$ wykonanych dochodów było 2209 jednostek (81,6\%). Regionalne Izby Obrachunkowe wezwały 31 jednostek samorządu do opracowania programu postępowania naprawczego, z czego 28 jednostek program taki opracowało (stan na 30.09.2015 r.). Udzielono też dwóm jednostkom, które znalazły się w trudnej sytuacji finansowej pomocy z budżetu państwa. 


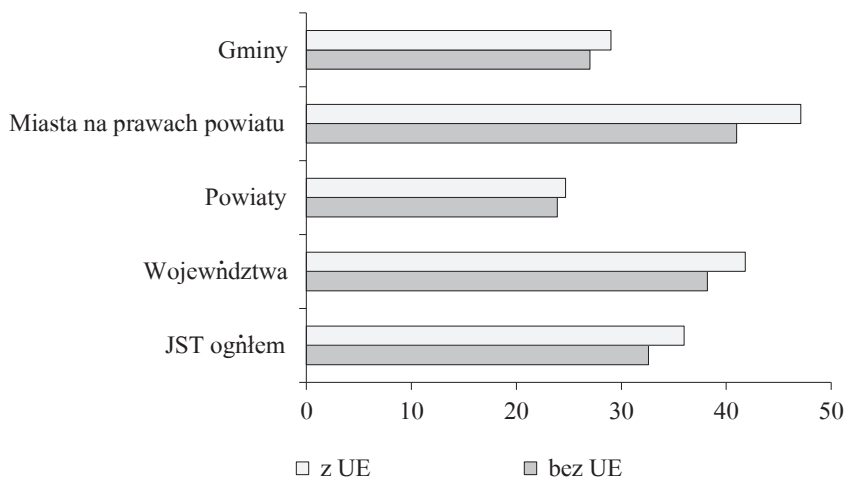

bez UE - bez zobowiązań na realizację programów i projektów finansowanych z udziałem środków unijnych; z UE - całość zobowiązań.

Rysunek 1. Wskaźnik zadłużenia do dochodów ogółem w 2015 roku (\%)

Źródło: Gospodarka (2016), s. 55.

W 2015 roku 78 jednostek samorządu terytorialnego nie spełniało relacji określonej indywidualnym wskaźnikiem zadłużenia, w tym 57 gmin, 20 powiatów, jedno miasto na prawach powiatu (Gospodarka, 2016, s. 55).

\section{Ocena wpływu pozyskania jednorazowych pomocowych środków zewnętrznych oraz zabezpieczenia środków na wkład własny z nadwyżki z lat ubieglych i posiadanych „wolnych środków” na poziom indywidualnego wskaźnika zadłużenia jednostki samorządu terytorialnego}

Bezzwrotne środki zewnętrze pozyskane do budżetu jednostki dają możliwość realizacji przedsięwzięć, których jednostka samorządu terytorialnego nie realizowałaby gdyby finansowała je w 100\% z własnego budżetu. Aplikując po środki zewnętrzne pochodzące z budżetu Unii Europejskiej lub funduszy celowych, jednostki zabezpieczają jedynie wkład własny - często na niskim poziomie stanowiącym np. 20\% wartości zadania - na realizację przedsięwzięcia, co minimalizuje wydatkowanie (angażowanie) własnych środków budżetowych.

Analizę wpływu pozyskania jednorazowych pomocowych środków zewnętrznych oraz zabezpieczenia środków na wkład własny z nadwyżki z lat ubiegłych i posiadanych ,wolnych środków" na poziom indywidualnego wskaźnik zadłużenia Powiatu Sulęcińskiego przeprowadzono wariantowo, a mianowicie:

Scenariusz 1. Do budżetu wprowadzono środki z przyjęcia dotacji na przedsięwzięcie bieżące trwające 2 lata, finansowane ze środków zewnętrznych w 100\% w kwocie $12 \mathrm{mln}$ zł po $6 \mathrm{mln}$ zł rocznie. Przedsięwzięcie będzie realizowane w 2017 i 2018 roku. 
Scenariusz 2. W budżecie uwzględniono środki pozyskane na realizację przedsięwzięcia bieżącego (projekt miękki) finansowanego np. w 80\% ze środków zewnętrznych, bezzwrotnych, pozyskanych z budżetu UE, które będą stanowić dochód bieżący i wydatek bieżący. 20\% wydatków bieżących projektu stanowi wkład własny sfinansowany z ,wolnych środków”. Przedsięwzięcie będzie realizowane w 2017 i 2018 roku. Wartość środków zewnętrznych (80\%) 4,8 mln zł stanowi dochód bieżący budżetu i wydatek bieżący budżetu, wkład własny jednostki (20\%) 1,2 mln zł stanowi wydatek bieżący budżetu. Kwota łączna wydatków to $6,0 \mathrm{mln}$ zł/po 3,0 $\mathrm{mln}$ zł rocznie.

Scenariusz 3. Po włączeniu jednorazowych bezzwrotnych środków zewnętrznych (przykład 1) oraz finansowania wkładu własnego ,wolnymi środkami” (scenariusz 2).

Scenariusz 4. Po uwzględnieniu wyłączania środków zewnętrznych ze scenariusza 1 i 2.

Wysokość wskaźnika spłaty zadłużenia w poszczególnych wariantach finansowania rozwoju jednostki samorządu terytorialnego zaprezentowano w tabeli 2.

\section{Tabela 2}

Indywidualny wskaźnik zadłużenia w poszczególnych wariantach finansowania rozwoju jednostki samorządu terytorialnego (\%)

\begin{tabular}{|c|c|c|c|c|c|c|c|c|c|}
\hline & \multicolumn{7}{|c|}{ Indywidualny wskaźnik zadłużenia } & \multirow{2}{*}{9.7} & \multirow{2}{*}{9.7 .1} \\
\hline & 9.1 & 9.2 & 9.3 & 9.4 & 9.5 & 9.6 & 9.6 .1 & & \\
\hline $\begin{array}{l}\text { For- } \\
\text { muła }\end{array}$ & 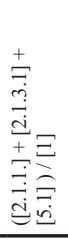 & 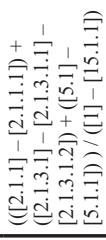 & & 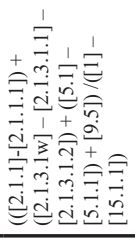 & 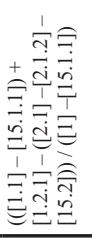 & $\begin{array}{l}\text { średnia } \\
\text { z trzech } \\
\text { poprzednich } \\
\text { lat }[9.5]\end{array}$ & $\begin{array}{l}\text { średnia } \\
z \text { trzech } \\
\text { poprzednich } \\
\text { lat }[9.5]\end{array}$ & 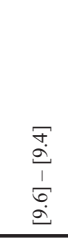 & $\begin{array}{l}7 \\
7 \\
\vdots \\
1 \\
\overline{0} \\
\vdots \\
\vdots\end{array}$ \\
\hline 1 & 2 & 3 & 4 & 5 & 6 & 7 & 8 & 9 & 10 \\
\hline \multicolumn{10}{|c|}{ Dane wyjściowe } \\
\hline 2017 & 1,39 & 1,39 & 0 & 1,39 & 2,44 & 3,03 & 5,30 & TAK & TAK \\
\hline 2018 & 2,20 & 2,20 & 0 & 2,20 & 3,28 & 3,45 & 5,72 & TAK & TAK \\
\hline 2019 & 2,01 & 2,01 & 0 & 2,01 & 4,21 & 3,02 & 5,29 & TAK & TAK \\
\hline 2020 & 2,52 & 2,52 & 0 & 2,52 & 4,41 & 3,31 & 3,31 & TAK & TAK \\
\hline 2021 & 3,20 & 3,20 & 0 & 3,20 & 5,03 & 3,97 & 3,97 & TAK & TAK \\
\hline \multicolumn{10}{|c|}{ Scenariusz pierwszy } \\
\hline 2017 & 1,23 & 1,23 & 0 & 1,23 & 2,15 & 3,03 & 5,30 & TAK & TAK \\
\hline 2018 & 1,94 & 1,94 & 0 & 1,94 & 2,88 & 3,35 & 5,62 & TAK & TAK \\
\hline 2019 & 2,01 & 2,01 & 0 & 2,01 & 4,21 & 2,79 & 5,06 & TAK & TAK \\
\hline 2020 & 2,52 & 2,52 & 0 & 2,52 & 4,41 & 3,08 & 3,08 & TAK & TAK \\
\hline \multicolumn{10}{|c|}{ Scenariusz drugi } \\
\hline 2017 & 1,32 & 1,32 & 0 & 1,32 & 0,85 & 3,03 & 5,30 & TAK & TAK \\
\hline 2018 & 2,09 & 2,09 & 0 & 2,09 & 1,57 & 2,92 & 5,19 & TAK & TAK \\
\hline 2019 & 2,01 & 2,01 & 0 & 2,01 & 4,21 & 1,92 & 4,19 & NIE & TAK \\
\hline 2020 & 2,52 & 2,52 & 0 & 2,52 & 4,41 & 2,21 & 2,21 & NIE & NIE \\
\hline
\end{tabular}




\begin{tabular}{|c|c|c|c|c|c|c|c|c|c|}
\hline 1 & 2 & 3 & 4 & 5 & 6 & 7 & 8 & 9 & 10 \\
\hline \multicolumn{10}{|c|}{ Scenariusz trzeci } \\
\hline 2017 & 1,17 & 1,17 & 0 & 1,17 & 0,75 & 3,03 & 5,30 & TAK & TAK \\
\hline 2018 & 1,85 & 1,85 & 0 & 1,85 & 1,39 & 2,88 & 5,16 & TAK & TAK \\
\hline 2019 & 2,01 & 2,01 & 0 & 2,01 & 4,21 & 1,82 & 4,10 & NIE & TAK \\
\hline 2020 & 2,52 & 2,52 & 0 & 2,52 & 4,41 & 2,12 & 2,12 & NIE & NIE \\
\hline \multicolumn{10}{|c|}{ Scenariusz czwarty } \\
\hline 2017 & 1,39 & 1,39 & 0 & 1,39 & 2,44 & 3,03 & 5,30 & TAK & TAK \\
\hline 2018 & 2,20 & 2,20 & 0 & 2,20 & 3,28 & 3,45 & 5,72 & TAK & TAK \\
\hline 2019 & 2,01 & 2,01 & 0 & 2,01 & 4,21 & 3,02 & 5,29 & TAK & TAK \\
\hline 2020 & 2,52 & 2,52 & 0 & 2,52 & 4,41 & 3,31 & 3,31 & TAK & TAK \\
\hline 2021 & 3,20 & 3,20 & 0 & 3,20 & 5,03 & 3,97 & 3,97 & TAK & TAK \\
\hline
\end{tabular}

9.1. Wskaźnik planowanej łącznej kwoty spłaty zobowiązań, o której mowa w art. 243 ust. 1 ustawy do dochodów, bez uwzględnienia zobowiązań związku współtworzonego przez jednostkę samorządu terytorialnego i bez uwzględniania ustawowych wyłączeń przypadających na dany rok.

9.2. Wskaźnik planowanej łącznej kwoty spłaty zobowiązań, o której mowa w art. 243 ust. 1 ustawy do dochodów, bez uwzględnienia zobowiązań związku współtworzonego przez jednostkę samorządu terytorialnego, po uwzględnieniu ustawowych wyłączeń przypadających na dany rok.

9.3. Kwota zobowiązań związku współtworzonego przez jednostkę samorządu terytorialnego przypadających do spłaty w danym roku budżetowym, podlegająca doliczeniu zgodnie z art. 244 ustawy.

9.4. Wskaźnik planowanej łącznej kwoty spłaty zobowiązań, o której mowa w art. 243 ust. 1 ustawy do dochodów, po uwzględnieniu zobowiązań związku współtworzonego przez jednostkę samorządu terytorialnego oraz po uwzględnieniu ustawowych wyłączeń przypadających na dany rok.

9.5. Wskaźnik dochodów bieżących powiększonych o dochody ze sprzedaży majątku oraz pomniejszonych o wydatki bieżące, do dochodów budżetu, ustalony dla danego roku (wskaźnik jednoroczny).

9.6. Dopuszczalny wskaźnik spłaty zobowiązań określony w art. 243 ustawy, po uwzględnieniu ustawowych wyłączeń, obliczony na podstawie planu 3 kwartału roku poprzedzającego pierwszy rok prognozy (wskaźnik ustalony na podstawie średniej arytmetycznej z 3 poprzednich lat).

9.6.1. Dopuszczalny wskaźnik spłaty zobowiązań określony w art. 243 ustawy, po uwzględnieniu ustawowych wyłączeń, obliczony na podstawie wykonania roku poprzedzającego pierwszy rok prognozy (wskaźnik ustalony na podstawie średniej arytmetycznej z 3 poprzednich lat).

9.7. Informacja o spełnieniu wskaźnika spłaty zobowiązań określonego w art. 243 ustawy, po uwzględnieniu zobowiązań związku współtworzonego przez jednostkę samorządu terytorialnego oraz po uwzględnieniu ustawowych wyłączeń, obliczonego na podstawie planu 3 kwartałów roku poprzedzającego rok budżetowy.

9.7.1. Informacja o spełnieniu wskaźnika spłaty zobowiązań określonego w art. 243 ustawy, po uwzględnieniu zobowiązań związku współtworzonego przez jednostkę samorządu terytorialnego oraz po uwzględnieniu ustawowych wyłączeń, obliczonego na podstawie wykonania roku poprzedzającego rok budżetowy.

Źródło: Uchwała (2017).

Analiza uzyskanych wielkości indywidualnego wskaźnika zadłużenia na tle danych wyjściowych pozwoliła na wyprowadzenie następujących wniosków:

1. Przyjęcie dotacji na przedsięwzięcie bieżące skutkuje pogorszeniem ustawowo wymaganego wskaźnika w 2019 i 2020 roku w stosunku do danych pierwotnych. W danym roku budżetowym wpływ dochodów na lewą stronę wzoru jest pozytywny, natomiast kiedy dany rok budżetowy upływa, a kwota dochodów, wynikająca z wykonania budżetu, przechodzi na prawą stronę wzoru (część historyczna), powiększa ona dochody budżetu ogółem o jednorazowe środki otrzymane na realizację przedsięwzięć, które znajdują się w mianowniku wzoru i obniżają średnią, która określa maksymalny poziom zadłużenia. 
2. Jednostka angażując środki budżetowe pochodzące z oszczędności z lat ubiegłych, „wolne środki” na zabezpieczenie wkładu własnego w zadaniu zwiększa wydatki bieżące budżetu, co od razu skutkuje pogorszeniem wymaganego ustawowo wskaźnika (scenariusz 2). Konsekwencją tego działania jest pogorszenie ustawowo wymaganego wskaźnika w 2019 i 2020 roku w stosunku do danych pierwotnych, i co istotne, w stopniu powodującym utratę możliwości uchwalenia budżetu w jednostce samorządu terytorialnego $\mathrm{w}$ roku 2020.

3. Łącząc wartość pozyskanych bezzwrotnych pomocowych środków (wprowadzonych do budżetu jednostki) z przedstawionych powyżej przykładowych działań można zaobserwować ich negatywny wpływ na ustawowo wymagany wskaźnik jednostki. Podejmowanie przedsięwzięć rozwojowych i realizacja głównych celów jednostki samorządu terytorialnego jest w tym scenariuszu - w świetle przyjętych regulacji zadłużenia - niemożliwa. Po wprowadzeniu jednorazowych bezzwrotnych środków pomocowych do budżetu, dzięki którym jednostka realizowała przedsięwzięcia bez dodatkowego zadłużania się, korzystając tylko ze środków własnych pochodzących z oszczędności („wolnych środków”), które zaangażowała jako wkład własny w wydatkach bieżących budżetu wywołała negatywne konsekwencje w postaci pogorszenia wskaźnika. Niespełnienie relacji, wynikającej ze wzoru indywidualnego wskaźnika zadłużenia, skutkuje opracowaniem i uchwaleniem programu postępowania naprawczego, czyli realizacji działań naprawczych głównie oszczędnościowych wskazanych w artykule 240a ust. 5 i 6 ustawy o finansach publicznych (Dz.U. 2016, poz. 1870). Wobec tego można dojść do wniosku, że jeżeli jednostka nie skorzystałaby z jednorazowych bezzwrotnych środków pomocowych nie miałaby problemów z dochowaniem wymaganych ustawowo relacji wskaźnikowych.

4. Pozytywny efekt działań rozwojowych finansowanych ze źródeł zewnętrznych można byłoby uzyskać po wyłączeniu jednorazowych, bezzwrotnych środków zewnętrznych oraz finansowania wkładu własnego „wolnymi środkami” z formuły obliczania indywidualnego wskaźnika spłaty zadłużenia. Problem ten dostrzeżono i w przeciwieństwie do wcześniej zgłaszanych propozycji modyfikacji wskaźnika (Marchewka-Bartkowiak, Wiśniewski, 2012, s. 3-6, za: Filipiak, Dylewski, 2013, s. 124-127) przewiduje się ich wprowadzenie (MF o zadłużeniu).

Reasumując, jednostki samorządu terytorialnego realizujące zadania bieżące współfinansowane ze środków zewnętrznych lub chcące wystąpić o dofinansowanie tych zadań, zabezpieczając środki na wkład własny z nadwyżki z lat ubiegłych i posiadanych „,wolnych środków” pogarszają swój indywidualny wskaźnik zadłużenia. W okresie przejściowym (stara ustawa - nowa ustawa) jednostki samorządowe przygotowując się do spełnienia wymogów wskaźnika w wielu przypadkach minimalizowały wydatki bieżące kosztem ograniczeń środków na zadania własne, wynagrodzenia. Zmniejszenia wydatków bieżących dokonano często nie z powodu braku środków, lecz ze względu na konieczność wygospodarowania nadwyżki dotyczącej bieżącej działalności wyłącznie po to, aby osiągnąć 
wymagany wskaźnik. Środki pozostające na rachunku, czyli zaoszczędzone przez jednostkę w latach wcześniejszych, a następnie wykorzystane jako wydatek bieżący budżetu, pogarszają relację wynikającą z obowiązującego wskaźnika (wywierają negatywny wpływ na prawą stronę wzoru). Wskaźnik nie wywołuje zatem pozytywnych działań. Jednostki działające gospodarnie, oszczędnie, niewydające wszystkich środków z budżetu w danym roku, podczas angażowania ich do budżetów lat przyszłych są wręcz karane pogarszaniem się wskaźnika. Podobnie jest z pozyskanymi jednorazowymi bezzwrotnymi środkami pomocowymi.

Kuriozalne jest to, że jednostka samorządu terytorialnego posiadając „wolne środki”, na rachunku bankowym nie może ich np. w dowolnej wysokości przeznaczyć na spłatę zaciągniętych wcześniej kredytów bądź pożyczek, gdyż maksymalną kwotę spłat określa właśnie obowiązujący wskaźnik. Wprowadzając wzór indywidualnego wskaźnika zadłużenia ustawodawca zapewne zamierzał zmniejszyć tempo przyrostu zadłużenia samorządów. Algorytm spłat skutecznie je ograniczył, lecz jednocześnie zablokował możliwości gospodarnego działania niezwiększającego zadłużenia. Wpływa to na sztuczne utrzymywanie zadłużenia w tych jednostkach. Wskaźnik zabezpiecza więc bardziej interes banków i prywatnych instytucji finansowych, niż interes publiczny samorządów.

Wyłączenie środków pomocowych i finansowania udziału własnego z wolnych środków z obliczanego wskaźnika nie zmniejszy gospodarności samorządów, a pozwoli korzystać w efektywny sposób z tych środków bez zwiększania zadłużania. Umożliwienie dokonywania spłat zadłużenia jednostki samorządu terytorialnego „wolnymi środkami” poza wskaźnikiem, spowoduje zmniejszenie kosztów obsługi zadłużenia (czyli odsetek od kredytów lub pożyczek), które stanowią wydatki bieżące w jednostce, a to pozytywnie wpłynie na prawą stronę obowiązującego wzoru. Zwiększy także możliwość aplikowania o środki pochodzące np. z budżetu Unii Europejskiej.

\section{Uwagi końcowe}

Przedstawione studium przypadku potwierdza zalety funkcji doradczej audytu wewnętrznego. Przeprowadzona analiza pozwoliła odnieść się do ryzyka finansowania rozwoju jednostki samorządu terytorialnego ze środków zewnętrznych. Wynikiem tej usługi jest sformułowanie postulatu, wyłączenia jednorazowych, bezzwrotnych środków zewnętrznych oraz finansowania wkładu własnego „wolnymi środkami” z formuły obliczania indywidualnego wskaźnika spłaty zadłużenia, a więc:

- pomniejszenie kwot dochodów planowanych w budżecie oraz kwot dochodów wykonanych budżetu o środki pochodzące $\mathrm{z}$ budżetu UE i funduszy celowych,

- pomniejszenie kwoty planowanych wydatków bieżących budżetu oraz kwoty wykonanych wydatków bieżących budżetu o kwoty planowanych i poniesionych wydatków na projekty współfinansowane z budżetu UE i funduszy celowych, 
- pomniejszenie kwoty wydatków bieżących budżetu przeznaczonych na wkłady własne pochodzące $\mathrm{z}$ budżetu jednostki samorządu terytorialnego do przedsięwzięć lub projektów.

Wprowadzone zmiany skutkowałyby urealnieniem przyjmowanych kwot dochodów ogółem oraz kwot wydatków bieżących, które uwzględnia się w przedmiotowym wzorze, a które są istotne dla wyliczeń wskaźnika indywidualnej spłaty zobowiązań zgodnie z zapisem art. 243 ustawy o finansach publicznych (Dz.U. 2016, poz. 1870).

W zakresie świadczenia usług doradczych istotne są trzy aspekty - klient, audyt oraz relacja kosztów i korzyści. Należy jednak pamiętać, że usługi doradcze, ze względu na swój charakter, wykonywane są zwykle w odpowiedzi na konkretne zapotrzebowanie zleceniodawcy - klienta. Ich zakres i jakość wynika z dojrzałości organizacji i dojrzałości funkcji audytu. Dojrzała organizacja ukierunkowana jest na ciągłe doskonalenie i oczekuje wzrostu zaangażowania audytu w procesy decyzyjne, a tym samym kładzie akcent na usługi doradcze. Ich szersze wykorzystanie umożliwia: wzrost efektywności działania, doprowadzenie do działania zgodnego z prawem, poprawę efektywności/skuteczności mechanizmów kontroli wewnętrznej, usprawnienie danego procesu, wprowadzenie procedur $\mathrm{w}$ danym procesie oraz ich aktualizację, wprowadzenie systemu monitorowania realizacji zadań, poprawę efektywności systemu komunikacji wewnętrznej i inne. Dojrzałość audytu zależy natomiast od kompetencji audytorów, stopnia poznania organizacji i możliwości racjonalnego zapewnienia o systemie kontroli zarządczej w jednostce. W realizacji funkcji doradczej istotna jest też ich efektywność, a więc korzyści powinny być większe niż poniesione z tego tytułu koszty (Kumpiałowska, 2017).

\section{Literatura}

Definicja audytu wewnętrznego. Kodeks etyki oraz międzynarodowe standardy praktyki zawodowej audytu wewnętrznego (2016). The Institute of Internal Auditors Reserch Fundation: Floryda. Tłumaczenie Warszawa: Instytut Audytorów Wewnętrznych IIA Polska.

Filipiak, B., Dylewski, M. (2013). Indywidualny wskaźnik zadłużenia jednostek samorządu terytorialnego - problemy dostosowawcze. W: J. Sokołowski, A. Żabiński (red.), Finanse publiczne. Wrocław: Wydawnictwo Uniwersytetu Ekonomicznego we Wrocławiu.

Gospodarka finansowa jednostek samorzadu terytorialnego 2015 (2016). Warszawa: Studia i analizy statystyczne, GUS.

Herdan, A., Stuss, M.S., Krasodomska, J. (2009). Audyt wewnętrzny: jako narzędzie wspomagajace efektywny nadzór korporacyjny w spółkach akcyjnych. Kraków: Wydawnictwo Uniwersytetu Jagiellońskiego.

Kabalski, P., Grzesiak, L. (2017). Funkcje audytu wewnętrznego w opinii polskich audytorów. Zeszyty Teoretyczne Rachunkowości, 91 (147).

Kumpiałowska, A., Wartość czynności doradczych audytu. Pobrane z: http:// www.mf.gov.pl/c/document_library/ get_file?uuid...36ec... (7.07.2017).

Marchewka-Bartkowiak, K., Wiśniewski, M. (2012). Indywidualny wskaźnik zadłużenia JST - ocena krytyczna i propozycje zmian. Analizy BAS, 21.

MF o zadłużaniu. Resort finansów przedstawił nowe przepisy dotyczace m.in. limitów zadłużenia. Pobrane z: http:// samorzad.pap.pl/depesze/redakcyjne.finanse/175026/MF-o-zadluzaniu--Resort-finansow-przedstawil-noweprzepisy-dotyczace-m-in--limitow-zadluzenia (7.07.2017).

Sprawozdanie z postępów realizacji w 2014 i 2015 r. Umowy Partnerstwa 2014-2020 (2016). Warszawa: Ministerstwo Rozwoju. Departament Koordynacji Wdrażania Funduszy Unii Europejskiej. 
Uchwała nr XXXV/170/17 Rady Powiatu Sulęcińskiego z dnia 25 kwietnia 2017 r w sprawie zmiany Wieloletniej Prognozy Finansowej Powiatu Sulęcińskiego na lata 2017-2030, Załącznika nr 1.

Ustawa z dnia 27 sierpnia 2009 r. o finansach publicznych (t.j. Dz.U. 2016 poz. 1870 z późn. zm.).

Winiarska, K. (2007). Audyt wewnętrzny w 2007 roku. Standardy międzynarodowe-regulacje krajowe. Warszawa: Difin.

\title{
FINANCING OF THE DEVELOPMENT OF A SELF-GOVERNMENTAL ENTITY BY EXTERNAL SOURCES AS AN ADVISORY TASK OF INTERNAL AUDIT
}

\begin{abstract}
Purpose - Identification of threats in absorption of external financing sources, including European Union (EU) funds in the perspective of years 2014-2020, in the realisation of soft and hard undertakings improving the quality of life of local communities.

Design/methodology/approach - Critical analysis of literature and other sources, risk analysis as well as a case study of the chosen administrative district.

Findings - The conducted research allowed the confirmation of the increasing importance of advisory function of internal audit as well as the existing threats in absorption of EU funds by self-governments and their determinants. In conclusion it was justified and confirmed that it is necessary to extend the list of exclusion used in calculating the individual debt rate.

Originality/value - The proposal and justification (in result of the realisation of advisory function of internal audit) of extending the list of exclusions taken into consideration while calculating the individual debt ratio, affecting the elimination of the barrier of the absorption of EU funds as well as the in improvement in economic actions in favour of the local community without increasing the debt.
\end{abstract}

Keywords: internal audit, advisory function, financing development, individual debt ratio

\section{Cytowanie}

Skoczylas, W., Kulczyńska, A. (2017). Finansowanie rozwoju jednostki samorządu terytorialnego ze źródeł zewnętrznych jako zadanie doradcze audytu wewnętrznego. Finanse, Rynki Finansowe, Ubezpieczenia, 3 (87/1), s. 31-41. DOI: 10.18276/frfu.2017.87/1-03. 